UDC: 351.85:352.07(497.1 Beograd)"1919/1939"

Jovana Babović

University of Illinois, Urbana-Champaign

Department of History

babovic1@illinois.edu
Original scientific paper received: $20^{\text {th }}$ March 2013 accepted: $1^{\text {st }}$ October 2013

\title{
MUNICIPAL REGULATION OF ENTERTAINMENT IN INTERWAR BELGRADE
}

\begin{abstract}
Between the two World Wars, and especially after 1929, the state's Belgrade City Authority was held to the task of policing the Yugoslav capital. Entertainment was an easy target of surveillance because popular imagination linked it with a slew of illegal activities such as gambling and prostitution. I argue that the urban administration played a significant role in defining and redefining the place of entertainment in Yugoslavia and its capital though the management of time, movement, and spatial use. The City Authority interpreted and implemented state agendas through the management of closing times, entertainers' residence permits, and public behavior. Regulation, however, did not succeed in controlling proprietors, performers, or patrons in the city; instead, it was oftentimes only successful at tempering the visibility of entertainment itself. I demonstrate that municipal regulation of entertainment in interwar Belgrade was largely ineffective due to its inconsistent implementation and resistance from the urban classes.
\end{abstract} Authority.

Keywords: entertainment, popular culture, 1920s, 1930s, urban life, Belgrade City

In 1936, the Association of Actors of Yugoslavia wrote to the Minister of Education to address a grievance on behalf of Tatjana Gez, a former actress employed as a dancer at the variety stage Krokodil in Belgrade. Gez complained that the owner pressured her to work as a barmaid after her performances, that she was forced to stay at the venue late into the night, and that her salary had not yet been paid. Indeed, according to the 1929 entertainment labor laws, Gez's accusations constituted multiple breaches. ${ }^{1}$ But her case was not unique. State and city archives are full of similar complains that testify both to the leaky administration of entertainment regulations and the persistent bottom-up defiance of city ordinances.

\footnotetext{
${ }^{1}$ Arhiv Jugoslavije, Ministarstvo prosvete (AJ, MP), Beograd, br. 360/111-254-936. Setting aside Gez's situation and the infraction of entertainment labor laws, the Association picked up the case as a platform to forward another concern to the state. The Association protested that Krokodil and many such establishments in the city were billed as "cheerful theaters" (vesela pozorišta), but that the genre hardly merits to be termed "theater." The Association believed that the improper use of the category was misleading and ultimately damaging to the reputation of "legitimate" theater.
} 
In reality, the Yugoslav state was too preoccupied with fundamental political problems following unification to offer a definitive cultural policy and to police its management in the capital. Working with the rich archival materials of the Ministry of Education, historian Ljubomir Dimić argues that interwar cultural policy was underdeveloped and lacked initiative and cohesion. ${ }^{2}$ In respect to entertainment, the state's policies were even less defined; state agencies were unsettled on whether entertainment was damaging to the development of "national oneness," if foreign performers threatened the rights of Yugoslav citizens, or if popular culture could be classified as culture at all. Especially after the onset of state centralization in 1929, the close link between urban ills and entertainment made commercial venues like cabarets and cinemas an easy target of surveillance. It was the state ancillary Belgrade City Authority that was held to the task of regulating urban order such as rowdy nighttime venues, illegal activities like gambling and prostitution, and immoral sexual behavior. The urban administration interpreted and implemented state agendas through the management of closing times, performers' residence permits, and public behavior. As we will see, regulation did not succeed in controlling proprietors, performers, or patrons in the city; instead, the urban administration was oftentimes only successful at tempering the visibility of entertainment itself. In this paper, I show that the regulation of entertainment in interwar Belgrade was largely ineffective due to inconsistent implementation and the urban classes' resistance to the new ordinances. Moreover, I argue that the urban administration played a significant role in defining and redefining the place of entertainment in Yugoslavia and its capital though the management of time, movement, and the use of space.

Restrictions on closing times were hotly contested in interwar Belgrade. After a decade of indifference, new municipal codes in 1929 required all nighttime establishments to close by 2 A.M. on the grounds that the late nights brought about excessive drunkenness and disturbance. In the months before the new closing time was to go into effect, a passionate reveler, who signed only as "Dude from Skadarlija" (Tip iz Skadarlije), penned an op-ed in the daily Novosti and expressed disbelief at the proposed ordinance; he dubbed Belgrade a "café-democracy" where ministers and government officials often enjoy wine, music, and "other nighttime pleasures." Similarly, the author saw nighttime fun as integral for the city's writers, artists, intellectuals, and actors, and threatened that they will "pack their bags" and turn their backs on Belgrade in the face of such regulations. But the author also spoke for ordinary urban residents, "all the city's Mišos, Markos, Savas, and Vladans," who enjoyed staying out well past 2 A.M. ${ }^{3}$ Another article put it simply: "Belgraders like to have fun at night."4

After the closing time ban went into effect, newspapers reported a domino effect: offenders were jailed and many business owners reported revenue loss. An article decried that negative economic repercussions were felt across the city - from hotels and cafés, to coachmen and food vendors. For instance, Ljubomir Simić, the manager of the café-bar

\footnotetext{
${ }^{2}$ Ljubomir Dimić, Kulturna politika Kraljevine Jugoslavije, 1918-1941, Tom I: Društvo i država, Beograd 1996, 17.

${ }^{3}$ Tip iz Skadarlije, Književni, umetnički i intelektualni Beograd sprema veliki miting protiv noćnog suvog režima, Novosti, 21. avgust 1928, 3 .

${ }^{4}$ Mesto novčane globe, policija hapsi kafedžije za otvorene radnje posle 2 časa, Novosti, 29. novembar 1929, 3.
} 
Crnogorac, was fined and jailed for disregarding the new closing time regulation. In his own defense, he claimed that his livelihood depended on nighttime operation because his main patrons - performers from the neighboring variety stage Palas - did not arrive before 2 A.M., when the theater drew its curtain. ${ }^{5}$ The journalist went on to elaborate that nightlife was a necessary niche in the city's economy. According to the article, the demand for night entertainment was exceptionally great and pointed to illegal "pop-up night houses" that continued to serve drinks and play music into the early morning hours. Unlike registered bars and clubs, these "night houses" were not licensed or taxed, and the article speculated that the closing restrictions forced law-abiding establishments into this same underworld of illegality in order to stay afloat financially. The immediate rejection of the new closing time ordinances can be described as a subtle yet significant form of subversion, as proprietors undermined municipal regulations and explicitly aligned themselves with the power of the entertainment market, rather than the authority of the urban administration. In disobeying urban ordinances for the sake of profit, the proprietors also put their faith in the continued late-night patronage of the urban public and the rooted place of entertainment in the city.

Spectators reacted against the sudden regulation of urban time by continuing to go out and stay out until dawn. Newspaper and magazines documented nightlife, and the enthusiastic coverage hardly revealed an awareness of the new municipal codes about closing times. A detailed cover story about "nighttime Belgrade" in the weekly magazine Ilustrovani list Nedelja featured more than twenty nightspots across the city, the places of entertainment where patrons went after the theater, operetta, or film. The author identified himself as a "night vagabond" and gleefully set out with a group of friends on "a night of debauchery paid for by the editorial offices." And, indeed, the author was met with lively crowds throughout the night. At the downtown hotel Ekscelizor, "powdered residents in tight tuxes marvel[ed] at the music and coolly dance[d] the diagonal waltz, ... as if at some dacha." At the Slavija and Ruska kruna further to the west, the author took part in a "dirty joke and good wine," while, at the pub Kragujevac, ladies who allowed themselves luxuries like fur and limos sat next to hard-working tradesmen and listened to the passionate sevdah singer Cica Stojanović. Other venues were notable for their orchestras, beautiful patrons, or exotic décor. But, what is most interesting is that the story wound through Belgrade - from the elegant clubs and café-bars of the center, to the pubs in the southern part of city and finally to the various outskirts - over the course of the night. Well after midnight, the tour of the city's night establishments took the author and his entourage to the outskirts "where the roads remain unpaved." Here, young men from the periphery and girls in colorful dresses danced and laughed with "sour wine and an out-oftune Roma upright bass." With seeming defiance of the ordinances, the author stayed out until dawn, when "the first roosters announce[d] the new day," precisely because the peripheral proprietors showed a similar disregard.

The municipal regulation of urban time had a powerful effect on the Belgraders' use of space: as the night wore on, nightlife grew more distant from the center, or went

\footnotetext{
${ }^{5}$ Ibidem.

${ }^{6}$ Kroz noćni Beograd..., Ilustrovani list Nedelja, 12. januar 1930, str. ii, 25.
} 
underground. Although scandals, intrigues, and illicit activity continued to appear in newspapers, the center's nightlife was increasingly roped off in the name of morality and respectability after 1929: in addition to closing times that budged only by special request, the styles of entertainment and the demographics of patrons were increasingly controlled. Downtown revelers, like the Austrian chocolatier Wilhelm Kutch [sic], moved the party into private quarters. While investigating Kutch's frequent trips to Vienna, the police found that he hosted private fetes (lumperajka) at his apartment in the city centrally located neighborhood Dorćol. ${ }^{7}$ But, more often, distance from the center came to signify a proportionate challenge to order, security, and good citizen behavior, and it was in Belgrade's outskirts where residents mobilized the cover of night to challenge top-down constructions of civic life quite publically. Nighttime amusements, prostitution, and drinking continued in peripheral neighborhoods like Propok near the rail station, the western Jagatan-mali, the eastern Danube shore Pištolj-mali where irregular policing and porous surveillance was more common. While these neighborhoods acquired a reputation of immorality and danger in the popular presses, not altogether divorced from ethnic, religious, and class components, they also fostered a space for diverse entertainment to remain a part of Belgrade's everyday life not far from the center.

Of course, municipal codes regulating entertainment were often undermined at all times of day and in all parts of the city. Police files point to endless raids of backroom gambling, some successful and others not, that uncover the popularity of this "luxurious" activity. ${ }^{8}$ Owners and servers often hid, warned, or helped patrons escape in light of encroaching police controls because gambling ultimately attracted customers, and their business, to bars and clubs. ${ }^{9}$ Prostitution was a more serious urban problem in the interwar years, and one not uncommonly linked with "fun and pleasure." Aleksandar Miletić suggests that "Belgrade authorities combated prostitution by targeting night cafés, so called Variétés, as they suspected that night performances were only a pretext for prostitution." 10 Among laws regulating public order after 1929, prostitution, pimping, and procuring of women and children was made illegal. ${ }^{11}$ In response to the heightened regulation of prostitution in the city, the activity withdrew into private places, underground, or away from the city center. In his memoirs, Dimitrije Knežev remembered going as far as Zemun's infamous brothel Kuća ljubavi (House of Love), on the other side of the Danube, as a part of a boyhood inauguration among students into "real citizens of the metropolis." "12 Many Belgraders, including Knežev's school friends, were well versed in the nighttime schedule of the ferry shuttling passengers upstream towards Zemun, just as they knew to follow the smell of tobacco, the rhythm of the waltz, and the chatter of the

\footnotetext{
${ }^{7}$ Istorijski arhiv Beograda, Uprava grada Beograda (IAB, UGB), Beograd, ČNV 2781, br. XXXIII/303/36.

${ }^{8}$ Naša nova anketa. Da li mi luksuziramo? Kako da štedimo?, Žena i svet, 15. april 1928, 10-11.

${ }^{9}$ IAB, UGB, ČNV 2800, br. 18/139/1939.

${ }^{10}$ Aleksandar R. Miletić, Insights into Urban Life, Cultural Change, and Modernization in the Kingdom of Serbs, Croats and Slovenes, 1918-1928, Urban Life and Culture in Southeastern Europe: Anthropological and Historical Perspectives (Eds. Klaus Roth and Ulf Brunnbauer) Berlin 2006, 195-210.

${ }^{11}$ Predrag Marković, Beograd i Evropa, 1918-1941: Evropski uticaj na process modernizacije Beograda, Beograd 1992, 62.

${ }^{12}$ Dimitrije M. Knežev, Beograd naše mladosti, 1918-1941, Beograd 2001, 133.
} 
crowd to "the street of love." Interwar Belgrade residents held Zemun's prewar AustroHungarian legacy responsible for the "cheerful atmosphere" and its reputation as the Eldorado of love where "sexual fun" was thought to be more liberal. Zemun was able to cultivate this reputation because prostitution was not illegal there. Moreover, another appeal, or, rather, legitimization, of Zemun's nightlife was the exoticism of the women employed at the brothels: they were usually Hungarian or Slovak. The category of foreignness was fundamental for enabling the social transgression of respectability that a visit to a brothel engendered. ${ }^{13}$

Meanwhile, in the capital, the City Authority struggled to regulate the boundaries of acceptable behavior of urban women. Nothing challenged the already unstable authority of "respectable" society as the visibility of female workers or patrons in places of entertainment. Although the police often lacked evidence necessary for an arrest or a medical exam, women who partook in nighttime fun were commonly suspected of prostitution. The fears of female sexuality reflect the anxieties of women's shifting role in urban society and social change in general. ${ }^{14}$ As Barbara Engel suggests, the enforcement of patriarchal order was often carried out through the regulation of women. ${ }^{15}$ A sevenpoint code specifically for female employees in bars, clubs, and variety theaters was passed in 1929 and stipulated that all employees must be reported, women cannot be lodged at the same address where they are employed, performers are to stop working by midnight and servers by 2 A.M., billed shows must be approved by the city authorities, employees are subject to screenings of skin and venereal disease, and workers are not to sit with guests at any time. ${ }^{16}$ Although this lengthy list of codes for employees was intended to protect women, it also revealed a patriarchal imposition of "respectable" behavior that was designed to protect society from female entertainment workers as well.

Female entertainers were of upmost concern because the mixing of performers and patrons blurred the lines of on- and off-stage entertainment and challenged the conventional practice of spectatorship. Under these pretensions, Đenadija Čolak, a 23 -year old singer at the pub Suvi deram was fined and imprisoned for two days after she was caught drinking with guests after her show, ${ }^{17}$ while Ana Hanover, an 18 -year old singer at Dalmatinac was similarly charged after she was found sitting with patrons at another pub. ${ }^{18}$ The heightened suspicion of female entertainers reflects the bourgeois fear of compromised morality and the corruption of society. Echoing the polarized patriarchal approaches to women in spaces of entertainment - as both victims and culprits - post1929 municipal regulations can be read as an attempt to protect the former and disarm the latter. In the case when the female entertainer were also a foreigner, the state and municipal authorities saw a clear opportunity to enforce not just respectability, but national respectability. A police memo hints at the degree to which national morality was

\footnotetext{
${ }^{13}$ Ibidem, 133-136.

${ }^{14}$ Dorothy Rowe, Representing Berlin: Sexuality and the City in Imperial and Weimar Germany, Aldershot 2003.

${ }_{15}$ Barbara Alpern Engel, Between the Fields and the City: Women, Work, and Family in Russia, 1861-1914, Cambridge 1994, 197.

${ }^{16}$ A. Miletić, Nav. delo, 206.

${ }^{17}$ IAB, UGB, ČNV 2800, br. 18/133.

${ }^{18}$ IAB, UGB, ČNV 2800, br. 18/131.
} 
at stake when the Greek performer Adela Bozaldis was accused of mixing with patrons in 1937. The police reported that Bozaldis was seen "in the company of different men with whom she visits different establishments, and it is suspected that the named here has adulterous relations with them and lives an immoral life." ${ }^{\text {"19 }}$ Bozaldis was consequently charged with "exploiting our hospitality" and her work and residence permits were revoked. Unlike a Yugoslav performer who would have been fined and imprisoned in this case, the Greek entertainer was expelled from the country and Bozaldis's file shows no further approved permits.

Yet, as with other interwar regulation, most proprietors disregarded the codes for female workers, just as city officials loosely monitored them. Managers often submitted performer dossiers to the Ministry of Internal Affairs, making no effort to hide that the entertainer's local lodging was, in fact, located at the same address as the employer. The restrictions on working hours were similarly disregarded, as was the case with the dancer Tatjana Gez. And, police records indicate that performers not only mingled with the public, but also developed intimate relations with local residents. For instance, the law student Spasoje Stefanović wrote to the Ministry of Internal Affairs in 1936 to request a permanent resident permit for the singer and dancer Ana Cinkova from Bulgaria, on the grounds of their forthcoming marriage. Stefanović explained that he met Cinkova while she was performing at the Ruski car and Palas in Belgrade, and pledged that he would bear the responsibility of supporting her from now on. Interestingly, the Minister approved the request, under the condition that Cinkova refrain from work at Belgrade's bars or variety stages. $^{20}$ The conditional residence permit alluded to the compartmentalized allocation of roles of female entertainers and women in general. Although Stefanović promised to shield Cinkova from further work in the entertainment industry, the Minister also asserted that after a marriage to the Belgrade law student, dancing and singing became an unsuitable profession. The fact that the Bulgarian performer did, indeed, apply for a subsequent work permit and her file shows that the request was granted, is a testament to the inconsistent administrative enforcement of municipal codes by both the city and the state.

The last of the 1929 municipal regulations of entertainment were vaguely aimed at reforming the spatial use of venues, including patron behavior and health codes. An article dated several months before the institution of the new regulations illustrated a typical evening atmosphere at a Belgrade cinema in the late 1920s. Many screening rooms were makeshift cinemas - adopted restaurants, pubs, or variety stages - that were packed to exceed capacity. The audience crowded at tables, while busy waiters served "Viennese schnitzel, ćevapčići and spritzers" from an improvised kitchen or bar. The commotion of taking orders, eating, and paying checks, coupled with the audience's general habit of whistling and hollering during projections, distracted from the film screenings. The author deemed this atmosphere provincial - how films were once watched in Paris, and how they are now screened in Priština or Debro; in other words, he argued that the local manifestation of the cinema as a part-pub, part-restaurant, and part-variety stage was ill

\footnotetext{
${ }^{19}$ Arhiv Jugoslavije, Ministarstvo unutrašnjih poslova (AJ, MUP), br. 40/434-503.

${ }^{20}$ AJ, MUP, br. 55/26.
} 
suited for a capital. ${ }^{21}$ While the author spoke in the name of film-lovers, he also revealed the awkward encounter between new forms of urban entertainment and the existing built infrastructure in Belgrade: this meant that performances were consumed out of context, shows were staged in improper settings, and, indeed, films were watched over the constant buzz of chewing, clinking, and clapping.

Although the City Authority was not necessarily interested in standardizing entertainment venues to the level of other European capitals, the core incentives were to rein in the unruliness, disorder, and immorality of the city. Most regulations that appeared after 1929 were presented as concerns for sanitation and safety, but indirectly worked to shape the experience of fun. For example, the cinema Avala was granted a conditional work permit extension on the grounds of a projection room inspection and the implementation of several new regulations: all films must be reported to the police a day ahead of scheduled screenings, the program must conclude by midnight, smoking must be prohibited, food brought into the hall must be "covered and hygienic," yelling, stomping, and whistling must be prohibited, and children cannot be allowed to projections of inappropriate films. ${ }^{22} \mathrm{~A}$ similar set of regulations was requested of the cinema Kasina, in addition to observing the hall's maximum capacity, keeping hygienic standards of food sold at the cinema, and employing a licensed projector operator. ${ }^{23}$ And, indeed, the bulk of these regulations were progressive initiatives to make film screenings more safe and pleasant, and many of them addressed the complaints of the film fan from 1928. But there was a good deal of subjectivity in the new codes of conduct; for instance, who deemed films inappropriate for minors? Invariably the bourgeois standards of respectability prevailed. At the same time it should be noted that, as with the effectiveness of other new urban codes, police records show that improper behaviors such as sexual harassment of female servers, ${ }^{24}$ dancing after midnight,${ }^{25}$ and fornication in back rooms ${ }^{26}$ continued to be a problem in entertainment venues.

Censorship was the last resort of controlling entertainment deemed "morally corrupt." There are cases when the city exerted power over the popular presses in the interest of the public's moral upkeep. In 1936, the Zagreb manufacturer Salus, standard aparati was banned from advertising its products - an array of pleasure-inducing tools such as condoms, penis pumps, birth control, and "menstrual underwear" - in Belgrade's magazines and newspapers. ${ }^{27}$ Likewise, cinemas were suspected of feeding foreign propaganda to an unassuming public. Initiatives to censor films "for security, health, moral, and political reasons" are seen in the Yugoslav archives as early as 1921, when the city was still grappling to understand this new form of entertainment. In 1925, the Belgrade City Authority petitioned to block films deemed to be offensive to religion, in

\footnotetext{
${ }^{21}$ Arhitektura bioskopa i naši kafanski bioskopi, Novosti, 18. avgust 1928, 4.

${ }^{22}$ IAB, UGB, ČNV 2776, br. I/1.

${ }^{23} \mathrm{IAB}, \mathrm{UGB}, \breve{C} N V 2781$, br. XXXIII/298.

${ }^{24}$ IAB, UGB, ČNV 2800 , br. $18 / 125$.

${ }^{25}$ IAB, UGB, ČNV 2800, br. 18/174.

${ }^{26}$ IAB, UGB, ČNV 2800, br. 18/136.

${ }^{27} \mathrm{IAB}, \mathrm{UGB}, \mathrm{C} \mathrm{NV} 2780$.
} 
poor artistic and moral taste, or thought to misrepresent Yugoslavia or other states. ${ }^{28}$ By the early 1930s, censorship of film "for public good" was paired with another urgent question: national consciousness. The president of the state-endorsed group Yugoslav Film sent a concerned note to the Minister of Education in 1933 claiming that upwards of $90 \%$ of movies screened in Yugoslavia are of German origin. The state eventually imposed a concrete method of nurturing national consciousness, promoting national filmmakers, and reserving the right to exclude certain foreign films. Cinemas were legally required to devote $7 \%$ of all screenings to domestic films in 1931, and $15 \%$ by 1932 . Because owners were fined time and again for noncompliance or for failing to screen any Yugoslav films at all, the regulation finally stabilized at a $10 \%$. Nonetheless this requirement often also went unfulfilled; ${ }^{29}$ the proprietor Ilija Đorđević excused himself by pleading that the demand for new films in Belgrade is overwhelming, and that there are simply too few Yugoslav films to be screened. ${ }^{30}$

The resistance of cinema owners and audiences to municipal regulations is one example of the participatory power of the urban classes. By subverting and rejecting the municipal regulations of entertainment - whether they were closing times, employee management, or operating standards - the proprietors, performers, and patrons undermined the authority of the city and the state. This challenge to urban management was confounded by the irregular surveillance and inconsistent regulation on the part of the Belgrade City Authority. Most importantly, entertainment in Belgrade, especially after 1929, garnered more attention from the state, the city, and the public; this scrutiny is a testament to entertainment's shifting importance in interwar Belgrade.

\section{Primary Sources:}

Archives:

Arhiv Jugoslavije, Ministarstvo prosvete

Arhiv Jugoslavije, Ministarstvo unutrašnjih poslova

Istorijski arhiv Beograda, Uprava grada Beograda

Newspapers:

Novosti, Ilustrovani list Nedelja, Žena i svet

Secondary Sources:

Dimić, Lj., Kulturna politika Kraljevine Jugoslavije, 1918-1941, Tom I: Društvo i država, Beograd 1996.

Engel, B., Between the Fields and the City: Women, Work, and Family in Russia, 1861-1914, Cambridge 1994.

Knežev, D., Beograd naše mladosti, 1918-1941, Beograd 2001.

\footnotetext{
${ }^{28}$ AJ, MP, br. 632/6-158.

${ }^{29}$ IAB, UGB, ČNV 2799, br. XVII/29-39.

${ }^{30}$ IAB, UGB, ČNV 2781, br. XXXIII/132.
} 
Marković, P., Beograd i Evropa, 1918-1941: Evropski uticaj na process modernizacije Beograda, Beograd 1992.

Miletić, A., Insights into Urban Life, Cultural Change, and Modernization in the Kingdom of Serbs, Croats and Slovenes, 1918-1928, Urban Life and Culture in Southeastern Europe: Anthropological and Historical Perspectives (Eds. Klaus Roth and Ulf Brunnbauer), Berlin 2006.

Rowe, D., Representing Berlin: Sexuality and the City in Imperial and Weimar Germany, Aldershot 2003. 


\title{
ГРАДСКА РЕГУЛАЦИЈА ЗАБАВНОГ ЖИВОТА У МЕЪУРАТНОМ БЕОГРАДУ
}

\begin{abstract}
Сажетак
У међуратном периоду, а посебно након 1929. године, Управа града Београда је постајала све више одговорна за одржавање реда у главном граду државе. Забавни живот у престоници је наметао потребу посебне пажње Управе града због честе повезаности са урбаним проблемима као што су проституција и коцкање. Својим настојањем да што више усклади ангажовање градске управе са државним наредбама, Управа града Београда је регулисала радно време ноћних локала, издавала радне дозволе артистима, и успостављала стандарде јавног реда. Заправо, регулисање времена, као и одређивање простора и кретања, одиграло је важну улогу у дефинисању односа забавног живота и града, као и државе. Управа није успела да реши многе градске проблеме којима су наредбе биле усмерене, успела је само да ускрати видљивост забавног живота у јавности. У раду се указује да је неусклађена примена нових закона и одупирање грађана градским прописима кочило регулацију забавног живота у међуратном периоду у Београду.
\end{abstract}

Кључне речи: забавни живот, популарна култура, међуратни период, урбани живот, Управа града Београда. 